\title{
The beetle Costalimaita ferruginea (Coleoptera: Chysomelidae) in Eucalyptus plantations in transition area of Amazon and Cerrado Biomes
}

\author{
T. K. R. Dias ${ }^{a}$, E. M. Pires ${ }^{a *}$, A. P. Souza ${ }^{b}$, A. A. Tanaka ${ }^{b}$,E. B. Monteiro ${ }^{b}$ and C. F. Wilcken \\ anstituto de Ciências Naturais Humanas e Sociais, Universidade Federal de Mato Grosso - UFMT, Campus de Sinop, \\ Av. Alexandre Ferronato, 1200, Distrito Industrial, CEP 78557-267, Sinop, MT, Brazil \\ 'Instituto de Ciências Agrárias e Ambientais, Universidade Federal de Mato Grosso - UFMT, Campus de Sinop, \\ Av. Alexandre Ferronato, 1200, Distrito Industrial, CEP 78557-267, Sinop, MT, Brazil \\ 'Departamento de Produção Vegetal, Faculdade de Ciências Agronômicas - FCA, Universidade Estadual Paulista \\ "Júlio de Mesquita Filho" - UNESP, Rua José Barbosa de Barros, 1780, CEP 18610-307, Botucatu, SP, Brazil \\ *e-mail: evaldo.pires@gmail.com
}

Received: March 28, 2016 - Accepted: June 7, 2016 - Distributed: February 28, 2018

(With 4 figures)

\begin{abstract}
Costalimaita ferruginea (Coleoptera: Chrysomelidae) attacks Eucalyptus plants causing severe damage through netting of the leaves. Recently, this Coleoptera has been reported attacking Myrtaceae in Mato Grosso State and, studies about the occurrence of this beetle in commercial plantations of eucalypts has been the subject of researchers through monitoring programmes in the forest protection area. With the beginning of the rainy season, adults were observed causing damage in eucalypt plantations in four cities that are part of the transition region of Amazon and Cerrado Biomes. The spots where these insects were observed are located in Feliz Natal, Lucas do Rio Verde, Sorriso and Vera. The purpose of this study was to report the new occurrences and to characterize the attack period of the beetle C. ferruginea in Eucalyptus plantations in Middle-North region of Mato Grosso State, region of Biomes Transition.
\end{abstract}

Keywords: damage, defoliator, new distribution, yellow beetle.

\section{O besouro Costalimaita ferruginea (Coleoptera: Chysomelidae) em plantios de Eucalyptus em áreas de transição dos Biomas Amazon e Cerrado}

\section{Resumo}

Costalimaita ferruginea (Coleoptera: Chrysomelidae) ataca plantas de Eucalyptus provocando intensos danos através do rendilhamento das folhas. Recentemente, esse Coleoptera tem sido relado atacando Myrtaceae no Estado de Mato Grosso e, estudos sobre a ocorrência desse besouro em plantios comerciais de eucaliptos tem sido alvo de pesquisadores através de programas de monitoramento na área de proteção florestal. Com o início do período chuvoso, adultos foram observados causando danos em plantios de eucalipto em quatro municípios que fazem parte da região de transição dos Biomas Amazônia e Cerrado. Os pontos onde foram observados esses insetos estão localizados em Feliz Natal, Lucas do Rio Verde, Sorriso e Vera. O objetivo deste trabalho foi relatar as novas ocorrências e caracterizar o período de ataque do besouro C. ferruginea em plantios de Eucalyptus na região Médio-Norte do Estado de Mato Grosso, região de transição de Biomas.

Palavras-chave: danos, desfolhador, nova distribuição, besouro amarelo.

\section{Introduction}

In Mato Grosso State, intensive silviculture with cultivation of Eucalyptus sp. is in its initial stage with around 59,980 ha and there are just a few registered pest insects causing damage (Shimizu et al., 2007; ABRAF, 2013). Among the leaf beetles, C. ferruginea, popularly known as "yellow beetle", stands out for its voracity and biotic potential (Santos et al., 2009; Zanuncio et al., 1993).
This species is considered a serious phytosanitary problem in Brazil, it has been accounted in Acre (Santos et al., 2016), Bahia (Mafia et al., 2014), Espírito Santo (Mafia et al., 2014), Goiás (Santos et al., 2003), Maranhão (Chagas and Coelho, 1974), Mato Grosso do Sul (Berti-Filho et al., 1980; Kassab et al., 2011), Minas Gerais (Freitas et al., 2002; Mafia et al., 2014; Pires et al., 2014; Santos et al., 2009), 
Pará (Maués and Couturier, 2002; Pinto et al., 2004; Lunz and Azevedo, 2014), Rio Grande do Norte (Mendes, 2004), Rio Grande do Sul e Paraná (Santos et al., 2009), Roraima (Marsaro-Júnior and Perreira, 2007), São Paulo (Mariconi, 1956; Junqueira, 1962), in Vale do Jari, between the States of Amapá and Pará (Lunz and Azevedo, 2014).

Besides these accounts, the Entomology Collection "Pe. Jesus S. Moure" of the Department of Zoology from Federal University of Paraná (DZUP) has some specimens deposited which collection records were in Ceará State and Pernambuco State (Information provided by Professor Germano H. Rosado Neto - UFPR). In Mato Grosso State, Costalimaita sp. was observed causing damage in seedling nursery in Sinop City (Pires et al., 2013).

The "yellow beetle" is considered small, measuring 5 to $6 \mathrm{~mm}$ long, it is bright yellowish-brown, its ventral region is orange, elytra with 15 to 18 longitudinal carinae and with small circular dots in relation to the end of the wing. Its adult life causes damage because they mainly feed on young leaves located in the upper third of the trees' crown, however, high population attack all the crown, reducing chlorophyllic parenchyma, giving the leaves a net-like appearance and drilling them, compromising the development and even may lead to death of the plants (Mendes et al., 1998; Santos et al., 2009). Their immature forms develop in the soil, where the larvae feed on the roots of grasses (Gould and Raga, 2002).
The information about the "yellow beetle" distribution in Mato Grosso is incipiente. Thus, the objective of this study was to broaden the reports of occurrence of $C$. ferruginea attacking commercial plantations of eucalyptus in the Middle-North of Mato Grosso State, transition region of Amazon Biome and Cerrado Biome.

\section{Material and Methods}

Samples were collected in commercial plantations of Eucalyptus grandis x Eucalyptus urophylla during the period from January 2014 to January 2016 in the cities of Feliz Natal, Lucas do Rio Verde, Sorriso and

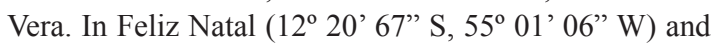
Vera ( $12^{\circ} 19^{\prime \prime} 63$ " S, $\left.55^{\circ} 19^{\prime} 01^{\prime \prime} \mathrm{W}\right)$ the plantations were located in the border of the Highway MT 225; in Sorriso (12 $51^{\prime}$ ' $98^{\prime \prime}$ S, 55 52' 93" W) and Lucas do Rio Verde ( $12^{\circ} 51^{\prime} 22^{\prime \prime} \mathrm{S}, 55^{\circ} 52^{\prime} 33^{\prime \prime} \mathrm{W}$ ) they were located in the border of Highway BR 163, in Mato Grosso State (Figure 1).

The areas were monitored with yellow sticky traps $(10 \times 12 \mathrm{~cm})$, trademark BIOTRAP ${ }^{\circledR}$ and, light traps model "Luíz de Queiroz", with UV fluorescente lamp (black light), 15 watts, powered by 12 -volt battery. All the sampled material was taken to the Laboratory of Energy and Pests from Agricultural and Environmental Sciences Institute of Federal University of Mato Grosso for screening, identification, and fixation of specimens.

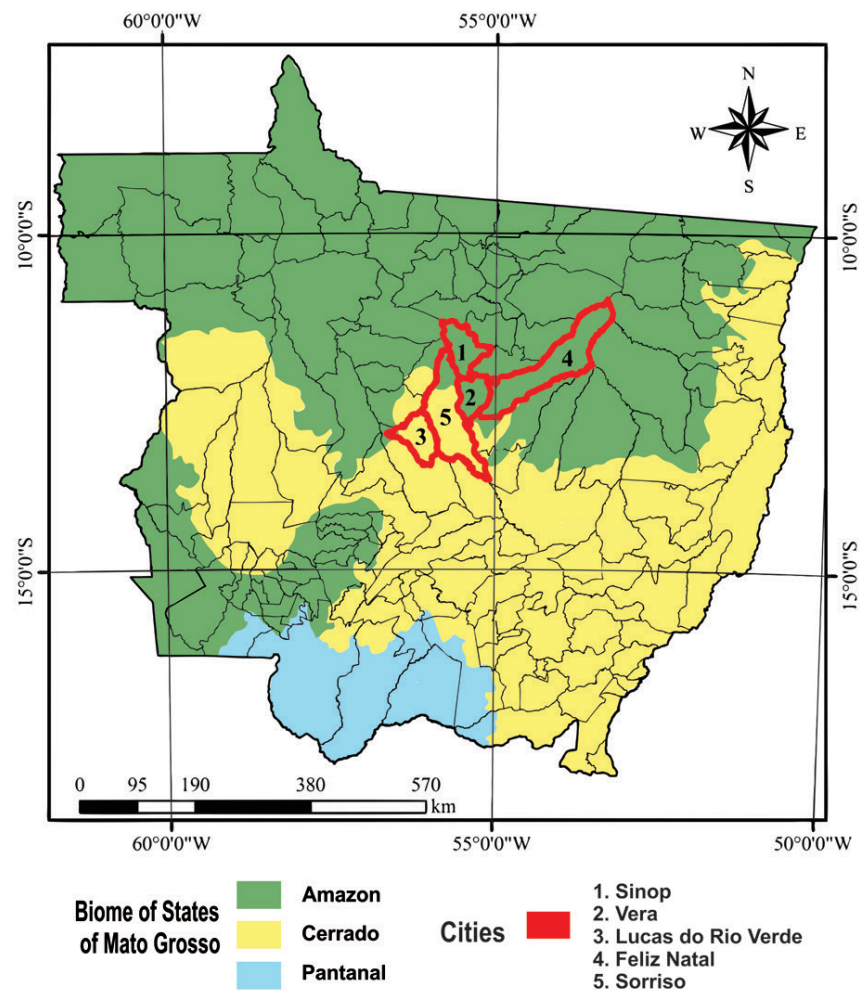

Figure 1. Map of the State of Mato Grosso, Brazil and its biomes. Emphasis on the cities where occurrence of Costalimaita ferruginea (Coleoptera: Chrysomelidae) were reported. (1) Sinop, (2) Vera, (3) Lucas do Rio Verde, (4) Feliz Natal, (5) Sorriso. 
Collected leaves in the field were conducted to the laboratory, 40 apical, middle and basal leaves were sampled, in three-year-old plantations bordered by native forested fragment, eucalyptus plantation and crops (soybeans) in Feliz Natal City, to obtain the real leaf area and consumed, with the aid of the photoelectric meter Li-Cor Li-300.

\section{Results}

The presence of $C$. ferruginea was found in all sampled areas and both ways of collection were effective in monitoring. In 2014, plants and leaves were observed with similar damage caused by $C$. ferruginea. With the beginning of the rainy season in the region (October, November) occurred the emergence of adults and the registration of damage only in samples carried out in Feliz Natal, MT (Figure 2). Compartments with plants of hybrid Eucalyptus grandis $\times$ Eucalyptus urophylla, bordered by native forested fragment and crop (soybean), were more affected by Chrysomelidae (Figure 2A, B). The photosynthetic area of plants was reduced, with perforated and net-like leaves. The consumption of leaf area was observed between $0-20 \%$ and more intense between $80-100 \%$ in eucalyptus leaves (Figure 3).

Eucalyptus plants bordered by native forested fragment showed higher percentage of leaf consumption in all thirds sampled due to the attack of C. ferruginea, however, higher percentages were recorded in the apical third, where most of the leaves showed consumption between 21 to $40 \%$,
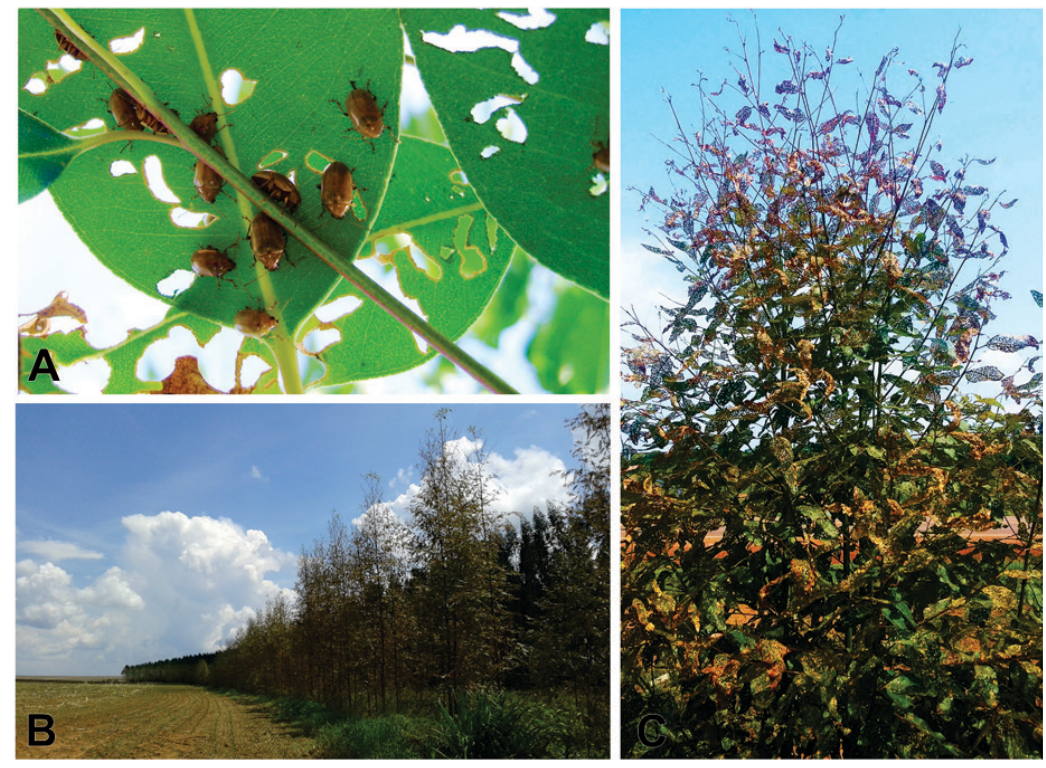

Figure 2. (A) Costalimaita ferruginea (Coleoptera: Chrysomelidae); (B, C). Damage on E. grandis x E. urophylla. Vera / Feliz Natal, Mato Grosso, Brazil.
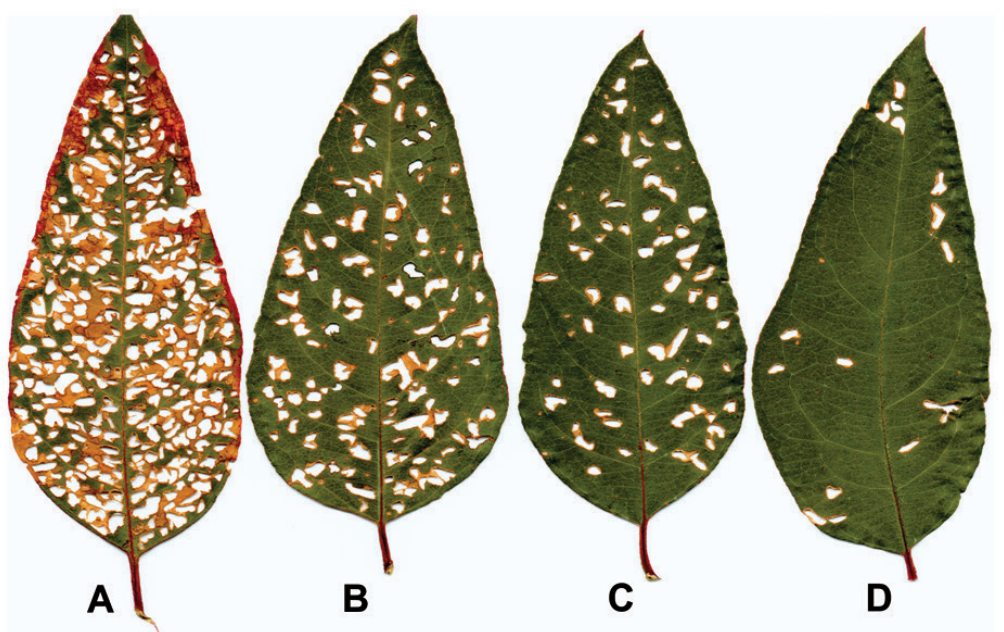

Figure 3. Leaves damage by Costalimaita ferruginea. (A) 81 a 100\%, (B) 41 a 60\%, (C) 21 a 40\%, (D) 0 a $21 \%$. 
Table 1. Leaf consumption of Costalimaita ferruginea (Coleoptera: Chrysomelidae) on Eucalyptus grandis $\times$ Eucalyptus urophylla.

\begin{tabular}{clll}
\hline \multicolumn{4}{c}{ Consumption percentage } \\
\hline Position & Apical & Middle & Basal \\
\hline E.F & $24.02 \mathrm{Aa}$ & $20.2 \mathrm{Aa}$ & $21.46 \mathrm{Aa}$ \\
E.E & $23.04 \mathrm{Aa}$ & $19.39 \mathrm{Aab}$ & $15.49 \mathrm{Bb}$ \\
E.L & $14.35 \mathrm{Bab}$ & $13.27 \mathrm{Bb}$ & $17.65 \mathrm{ABa}$ \\
\hline
\end{tabular}

Averages followed by the same letter in the column and lowercase latter in line do not differ by Tukey test at 5 (\%) probability. E. F. Eucalyptus plantation bordered by native forested fragment. E.E. Eucalyptus plantation bordered by eucalyptus. E. L. Eucalyptus plantation bordered by crops.

according to the range by Montes et al. (2012). Plants bordered by crops, and during sampling period with soybean crops, obtained lower percentage of leaf consumption in the apical and middle thirds, lower than plants bordered by native forested fragment and eucalyptus plantations, despite that, the basal third showed no significant difference to other positions evaluated. The leaves of the basal third of eucalyptus plantations were less consumed (Table 1).

In 2015 , in the same period with the onset of rains, the presence of this beetle was also recorded in other monitored localities, in the cities of Vera, Sorriso and Lucas do Rio Verde (Figure 2). Compartments of the same hybrid showed defoliation signs and burned leaves. In Vera City, one-year-old plants were the most attacked ones, with $3 / 4$ or more of their destroyed crown and apical parts due to $C$. ferruginea attack in accordance with attack intensity levels recommended by Mazanec (1966). In other locations the plants were also attacked, but with less intensity, possibly due to the age of the plants that were between two and four years old. Light traps enabled the collection of beetles in January of 2015 and 2016 in all sampled locations.

\section{Discussion}

Leaves in all thirds of the plants were attacked, with predominant attack on young leaves. It is Worth mentioning that in periods of higher temperature range, the beetles take shelter in the abaxial part of the leaves. Attacks with similar characteristics were recorded by Pires et al. (2013), preference for young leaves in apical and lateral parts with insects sheltered under leaves and lower feeding activity in the hottest periods of the day.

The pattern of damage inflicted on the leaves described by Anjos et al. (1990), netting, occurred in all sampled locations and years (Figure 1B, C), varying only the intensity of the attack on plants, and this characteristic is an indicative of the occurrence of defoliating Chrysomelidae in the area (Mendes, 2004).

Part of the development cycle of $C$. ferruginea occurs on the ground, its immature stage, feeding on roots (Mendes et al., 1998; Montes et al., 2012). Possibly, the proximity of eucalyptus planted areas to native forested fragment enables the development of a greater number of larvae of the coleopteran, generating larger amount of adults, due to the absence or reduced anthropic interference on the ground in this fragment, reducing the exposure of larvae to predators, parasitoids and even climate factors, such as high temperature during soil preparation period for the implantation of soybean cultivation in Amazon-Cerrado region, between the months of August and September (Souza et al., 2012).

This proximity also allows the provision of food resources for this phytophagous due to constant regrowth of plants and formation of new roots inside the native forested fragment. Favero et al. (2011) reports greater abundance and diversity of Chrysomelidae in forested fragments in an advanced stage of restoration when compared to fragments in the early stages of restoration, this fact is attributed to the diversity of food source for phytophagous insects.

Young leaves of the apical third were preferred (Table 1), and the reduction of leaf area in this third may cause major economic losses, to the detriment of the reduction in mature leaves (Anjos and Majer, 2003). The preference for younger leaves is directly linked to nutritional quality, high nitrogen levels and lower levels of essential oils which provide high levels of defoliation (Ohmart et al., 1985; Baker at al., 2002). In Southeast Brazil, E. camaldulensis, E. urophylla, E. grandis, and hybrids E. grandis $x$ E. urophylla ("urograndis") show leaves with higher percentage of damage between 21 and $100 \%$ of leaf area consumed by $C$. ferruginea (Montes et al., 2012).

The period of occurrence of "yellow beetle" in Middle-North region of Mato Grosso with standard Amazon-Cerrado transition vegetation, is similar to that found in the Southeast region of the country, during the rainy season, as evidenced by Mendes et al. (1998), Freitas et al. (2002), Montes et al. (2012) and Pires et al. (2014). However, the rainy season in Mato Grosso region with water excess is between October and April, with annual accumulated precipitation of $1974.47 \mathrm{~mm}$ (Souza et al., 2012, 2013). This difference of over 30 days of rainy period, when compared to brazilian Southeast, October to March, (Alves et al., 2005; Minuzzi et al., 2007), favors the beetle cicle, promoting the development of the larva over time due to moisture in the soil (Figure 4).

Despite all areas had been monitored for two years, only in the city of Feliz Natal was confirmed the presence of the beetle, 36 insects, during the first year, possibly due to the transportation of seedlings infected with larvae in the substrate, contributing to the distribution of $C$. ferruginea or even the proximity to areas of forested fragments and, or farming, considering the preference of this beetle in 


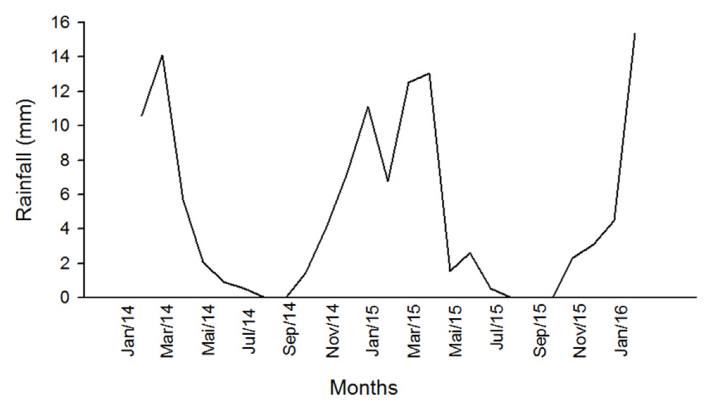

Figure 4. Rainfall in Middle-North of Mato Grosso, Brazil between 2014 and 2016 .

grass roots, behavior reported by Gould and Raga (2002), since this region of Mato Grosso is a major grain producer in Brazil, soybean-corn succession and pasture used in cattle-raising.

Little is known about $C$. ferruginea behavior, especially as the scenery changes, but, like other beetles, this is sensitive to environmental changes, in a special way in biomes transition areas (Andresen, 2001; Rodrigues et al., 2013).

\section{Acknowledgements}

To the "Coordenação de Aperfeiçoamento de Pessoal de Nível Superior (CAPES)", "Conselho Nacional de Desenvolvimento Científico e Tecnológico (CNPq)", the "Fundação de Amparo à Pesquisa do Estado de Mato Grosso - FAPEMAT" and the "Instituto de Estudos e Pesquisas Florestais (IPEFF - PROTEF)".

\section{References}

ALVES, L.M., MARENGO, A., JÚNIOR, H.C. and CASTRO, C., 2005. Início da estação chuvosa na região sudeste do Brasil: Parte 1 - Estudos observacionais. Revista Brasileira de Meteorologia, vol. 20, no. 3, pp. 385-394.

ANDRESEN, E., 2001. Effects of dung presence, dung amount, and secundary dispersal by dung Beetles on the fate of Micropholis guyanensis (Sapotaeae) seeds in Central Amazonia. Journal of Tropical Ecology, vol. 17, no. 1, pp. 61-78. http://dx.doi. org/10.1017/S0266467401001043.

ANJOS, N. and MAJER, J.D., 2003. Leaf-eating Beetles in Brazilian eucalypt plantations. Curtin: School of Environmental Biology. 33 p. Bulletin, no. 23.

ANJOS, N., BERTI-FILHO, E. and ALVES, S.B., 1990. Ocorrência de Beauveria e Metarhizium em besouro amarelo dos eucaliptos. Revista de Agricultura, vol. 65, no. 3, pp. 279-280.

ASSOCIAÇÃO BRASILEIRA DE PRODUTORES DE FLORESTAS PLANTADAS - ABRAF, 2013. Anuário estatístico 2013 ano base 2012. Brasília. 148 p.

BAKER, S.C., ELEK, J.A. and CANDY, S.G., 2002. Comparison of feeding efficiency, development time and survival of Tasmanian eucalyptus leaf beetle larvae Chrysophtharta bimaculata (Olivier) (Coleoptera: Chrysomelidae) on two hosts. Australian
Journal of Entomology, vol. 41, no. 2, pp. 174-181. http://dx.doi. org/10.1046/j.1440-6055.2002.00286.x.

BERTI-FILHO, E., MENDES-FILHO, J.M.A. and KRÜGNER, T.L., 1980. Pragas e doenças de Eucalyptus na região do Mato Grosso do Sul. IPEF: Circular Técnica, vol. 106, pp. 1-12.

CHAGAS, E.F. and COELHO, I.P., 1974. "Besouro amarelo", Costalimaita ferruginea vulgata (LEFREVE, 1885) danificando algodão herbáceo no Maranhão. São Luis: Secretaria da Agricultura do Estado do Maranhão. 7 p.

FAVERO, S., SOUZA, H.A. and OLIVEIRA, A.K.M., 2011. Copleoptera (INsecta) as forest fragmentation indicators in the Rio Negro sub-region of the Pantanal, Mato Grosso do Sul Brasil. Brazilian Journal of Biology $=$ Revista Brasileira de Biologia, vol. 71, no. 1, suppl. 1, pp. 291-295. PMid:21537602. http:// dx.doi.org/10.1590/S1519-69842011000200008.

FREITAS, F.A., ZANUNCIO, T.V., LACERDA, M.C. and ZANUNCIO, J.C., 2002. Fauna de Coleoptera coletada com armadilhas luminosas em plantios de Eucalyptus grandis em Santa Bárbara, Minas Gerais. Revista Árvore, vol. 26, no. 4, pp. 505-511. http://dx.doi.org/10.1590/S0100-67622002000400014.

GOULD, W.P. and RAGA, A., 2002. Pests of guava. In: J.E. PEÑA, J.L. SHARP and M. WYSOKI, eds. Tropical fruit pests and pollinators: biology, economic importance, natural enemies and control. New York: CABI Publishing, pp. 295-313.

JUNQUEIRA, G.M., 1962. Nota sobre o "besouro amarelo dos eucaliptais. O Biológico, vol. 28, pp. 326-328.

KASSAB, S.O., MOTA, T.A., PEREIRA, F.F. and FONSECA, P.R.B., 2011. Primeiro relato de Costalimaita ferruginea (Fabricius, 1801) (Coleoptera: Chrysomelidae) em eucalipto no Estado do Mato Grosso do Sul. Ciência Florestal, vol. 21, no. 4, pp. 777780. http://dx.doi.org/10.5902/198050984522.

LUNZ, A.M. and AZEVEDO, R., 2014. Caracterização da ocorrência do esouro-amarelo, Costalimaita ferruginea (Fabricius) (Coleoptera: Chrysomelidae), em plantios de Eucalipto no Pará. Belém: Embrapa. 5 p. Comunicado Técnico, no. 229.

MAFIA, R.G., MENDES, J.E.P. and CORASSA, J.D.N., 2014. Análise comparativa dos surtos e danos causados pelos besouros desfolhadores Costalimaita ferruginea (Fabricius, 1801) e Costalimaita lurida (Lefévre, 1891) (Coleoptera: Chrysomelidae) em plantios de eucalipto. Revista Árvore, vol. 38, no. 5, pp. 829-836. http://dx.doi.org/10.1590/S0100-67622014000500007.

MARICONI, F.A.M., 1956. Alguns besouros depredadores de eucaliptos na região de Piracicaba. O Biológico, vol. 22, no. 1, pp. 1-14.

MARSARO-JÚNIOR, A.L. and PERREIRA, P.R.V.S., 2007. Insetos-praga da Acacia mangium em Roraima. Roraima: Embrapa. 12 p.

MAUÉS, M.M. and COUTURIER, G., 2002. Biologia floral e fenologia reprodutiva do Camu-camu (Myrciaria dubbia (H.B.K.) Mc Vaugh, Myrtaceae) no estado do Pará, Brasil. Brazilian Journal of Botany, vol. 25, no. 4, pp. 441-448. http://dx.doi.org/10.1590/ S0100-84042002012000008.

MAZANEC, Z., 1966. The effect of defoliation by Didmuria violescens (Phasmatidae) on the growth of Alpine Ash. Australian Forestry, vol. 30, no. 2, pp. 125-130. http://dx.doi.org/10.1080/ 00049158.1966 .10675405 .

MENDES, J.E.P., 2004. Efeitos do ataque de Costalimaita ferruginea (Fabr.) (Coleoptera: Chrysomelidae) sobre crescimento 
e produção de Eucalyptus grandis (Hill ex Maiden). Viçosa: Universidade Federal de Viçosa, 61 p. PhD Thesis.

MENDES, J.E.P., ANJOS, N. and CAMARGO, F.R.A., 1998. Monitoramento do besouro-amarelo. Folha Florestal, vol. 91, no. 1, pp. 8-9.

MINUZZI, R.B., SEDIYAMA, G.C., BARBOSA, E.M. and MELO JÚNIOR, J.C.F., 2007. Climatologia do comportamento do período chuvoso da região Sudeste do Brasil. Revista Brasileira de Meteorologia, vol. 22, no. 3, pp. 338-344. http://dx.doi. org/10.1590/S0102-77862007000300007.

MONTES, S.M.N.M., SATO, M.E., RAGA, A. and CERÁVOLO, L.C., 2012. Avaliação de danos de adultos de Costalimaita ferruginea (Fabricius) (Col.: Chrysomelidae) em Eucalyptus spp. na região de Presidente Prudente, SP. Arquivos do Instituto Biologico, vol. 79, no. 3, pp. 431-435. http://dx.doi.org/10.1590/ S1808-16572012000300017.

OHMART, C.P., STEWART, L.G. and THOMAS, J.R., 1985. Effects of food quality, particularly nitrogen concentrations, of Eucalyptus blakelyi on the growth of Paropsis atomaria (Coleoptera: Chrysomelidae). Oecologia, vol. 65, no. 4, pp. 543-549. http:// dx.doi.org/10.1007/BF00379670.

PINTO, R., ZANUNCIO JÚNIOR, J.S., ZANUNCIO, T.V., ZANUNCIO, J.C. and LACERDA, M.C., 2004. Coleópteros coletados com armadilhas luminosas em plantio de Eucalyptus urophylla na Região Amazônica Brasileira. Ciência Florestal, vol. 14, no. 1, pp. 111-119.

PIRES, E.M., CORASSA, J.N., BARRETO, M.R. and SOARES, M.A., 2013. New Report of Costalimaita ferruginea (Fabricius) (Coleoptera: Chrysomelidae) on Eucalyptus sp. (Myrtaceae) in Sinop - Mato Grosso, Brazil. EntomoBrasilis, vol. 6, no. 1, pp. 89-90. http://dx.doi.org/10.12741/ebrasilis.v6i1.207.

PIRES, E.M., CORASSA, J.N., NOGUEIRA, R.M., OLIVEIRA, M.A., MANICA, C.L.M., FERREIRA, J.A.M. and SOARES, M.A., 2014. New geographical distribution and seasonality of Costalimaita ferruginea (Coleoptera: Chrysomelidae) on
Eucalyptus "urograndis" in Guiricema, Minas Gerais, Brazil. Scientific Electronic Archives, vol. 5, pp. 1-4.

RODRIGUES, M.M., UCHÔA, M.A. and IDE, D., 2013. Dung Beetles (Coleoptera: Scarabaeoidea) in tree landscapes in Mato Grosso do Sul Brazil. Brazilian Journal of Biology $=$ Revista Brasileira de Biologia, vol. 73, no. 1, pp. 211-220. PMid:23644804. http://dx.doi.org/10.1590/S1519-69842013000100023.

SANTOS, G.P., ZANUNCIO, J.C., OLIVEIRA, H.G., ZANUNCIO, T.V. and LACERDA, M.C., 2003. Coleopteros coletados em plantação de Eucalyptus urophlla S. T Blake (Myrtaceae) na Região de Niquelândia, estado de Goiás, Brasil. Bioscience Journal, vol. 19, no. 3, pp. 77-82.

SANTOS, G.P., ZANUNCIO, J.C., ZANUNCIO, T.V. and PIRES, E.M., 2009. Pragas do Eucalipto. Informe Agropecuário, vol. 29, no. 1 , pp. 43-64.

SANTOS, R. S., GONÇALVES, R. and SILVA, N.A., 2016. Primeiro registro do besouro-amarelo-do-eucalipto em plantios de eucalipto no Estado do Acre. Revista Ceres, vol. 63, no. 4, pp. 584-587. http://dx.doi.org/10.1590/0034-737X201663040020.

SHIMIZU, J.Y., KLEIN, H. and OLIVEIRA, J.R.V., 2007. Diagnóstico das plantações florestais em Mato Grosso. Cuiabá: Central de Texto. 63 p.

SOUZA, A.P., CASAVECCHIA, B.H. and STANGERLIN, D.M., 2012. Avaliação dos riscos de ocorrência de incêndios florestais nas regiões Norte e Noroeste da Amazônia Matogrossense. Scientia Plena, vol. 8, no. 5, pp. 1-14.

SOUZA, A.P., MOTA, L.L., ZAMADEI, T., MARTIM, C.C., ALMEIDA, F.T. and PAULINO, J., 2013. Classificação climática e balanço hídrico climatológico no Estado de Mato Grosso. Nativa: Pesquisas Agrárias e Ambientais, vol. 1, no. 1, pp. 34-43. http:// dx.doi.org/10.14583/2318-7670.v01n01a07.

ZANUNCIO, J.C., BRAGANCA, M.A.L., LARANJEIRO, A.J. and FAGUNDES, M., 1993. Coleópteros associados a eucaliptocultura nas regiões de São Mateus e Aracruz, Espirito Santo. Revista Ceres, vol. 40, no. 232, pp. 584-590. 